на соискание учен. степени канд. вет. наук: спец. 16.00.02 «Патология, онкология и морфология животных». Москва, 2009. 23 с.

2. Сысуева А.В., Уша Б.В. Исследование морфофункциональных изменений эритроцитов крови при патологиях печени у мелких домашних животных. Ветеринарная клиника. Екатеринбург. 2008. № 1(68). C. 12-14.

3. Сысуева А.В. Исследование системы эритрона у собак и кошек при патологиях печени. Российский ветеринарный журнал ветеринарный журнал. Москва. 2008. № 4. С. 7-9.

4. Кирк Р., Бонагура Д. Современный курс ветеринарной медицины Кирка: пер. с англ. Москва. ООО «Аквариум принт». 2005. 1376 с.

5. Корчагина О.С. Диагностика и лечение гепатоза у служебных собак: автореф. дис. на соискание учен. степени канд. вет. наук: спец. 16.00.01 «Диагностика болезней и терапия животных». Воронеж. 2008. $23 \mathrm{c}$.

6. Йин С. Полный справочник по ветеринарной медицине мелких домашних животных: пер. с англ. Москва. Аквариум-принт. 2008. $1024 \mathrm{c}$.

7. Морозенко Д.В. Біохімічні показники метаболізму сполучної тканини у діагностиці захворювань дрібних домашніх тварин: монографія. Харків, $2011.120 \mathrm{c}$.

8. Колодий И.В., Живая С.С. Ультразвуковая диагностика некоторых заболеваний печени у собак. Ветеринария Кубани. 2009. № 4. C. $11-12$.

DOI https://doi.org/10.30525/978-9934-588-81-5-1.56

\title{
МОРФОЛОГІЧНІ ЗМІНИ ЗА ХРОНІЧНОЇ ХВОРОБИ НИРОК ДОМАШНІХ КОТІВ
}

\author{
Морозенко Д. В. \\ доктор ветеринарних наук, \\ завідувач кафедри ветеринарної медицини та фармації \\ Національний фармащевтичний університет \\ Захар'єв А. В. \\ кандидат ветеринарних наук, \\ дочент кафедри ветеринарної медицини та фармачії \\ Національний фармачевтичний університет
}


Доценко Р. В.

кандидат ветеринарних наук, доцент кафедри ветеринарної медицини та фармачії

Начіональний фармацевтичний університет

Землянський А. $О$.

кандидат ветеринарних наук,

асистент кафедри ветеринарної медицини та фармації

Національний фармацевтичний університет

Селюкова Н. Ю.

кандидат біологічних наук,

асистент кафедри ветеринарної медицини та фармації

Національний фармацевтичний університет

м. Харків, Україна

Хронічна хвороба нирок (XXН) є досить актуальною проблемою сучасної нефрології котів [1, с. $310 ; 2$, с. 526 ; 3, с. 79; 4, с. 1355]. Морфологічне дослідження нирок домашніх котів $є$ посмертним методом діагностики хронічної хвороби нирок (ХНH) [5, с. 149]. Було досліджено морфологічно нирки трьох котів, які загинули внаслідок розвитку та прогресування синдрому XXН на різних стадіях. Стадії XXH встановлювали згідно International Renal Interest Society (IRIS) [6, c. 527].

II стадія XXН. Мікроскопічне дослідження нирки кішки, яка загинула а II стадії XXН (вміст креатиніну у сироватці крові 171,0 мкмоль/л), показало неоднозначну картину. Частина ниркових тілець були звичайного розміру, капсула - тонкою, рисунок кровоносних петель досить виразний, у деяких петлях проглядалися еритроцитарні стази. За даними літератури, відсутність чітких змін у капсулі частини ниркових тілець відповідає стадії пресклерозу - початковій стадії розвитку захворювання. У ряді клубочків ниркових тілець було видно сегментарний гіаліноз, часто спостерігалися локальні гіалінові i фібриноїдні відкладення у просвіті капсули і субендотеліально, клітини ендотелію капілярів були збільшені, спостерігалась вакуолізація їх цитоплазми. Частина клубочків ниркових тілець була ішемічна і зморщена, був виражений перигломерулярний склероз, а також склероз капілярних петель різної інтенсивності. Зустрічалися також повністю склерозовані клубочки. Наявність таких змін у клубочках вказує на розростання сполучної тканини із визначеною локалізацією процесу, але при цьому зберігається форма нирок. Фарбування гістопрепаратів 
за Ван-Гізоном дозволяе визначати сполучнотканинний каркас склеротичної нирки за рахунок вибіркового забарвлення колагенових волокон у рожевий колір. У проксимальних і дистальних частинах канальців нефронів спостерігалась виражена гідропічна і жирова дистрофія. Гідропічна дистрофія була відзначена у трубочках мозкових променів. Видно розвиток осередкового склерозу строми нирок, особливо у ділянці мозкових променів, а також лімфо-гістіоцитарна інфільтрація строми. Відзначено також помірний склероз перивазальної тканини. У середній оболонці артерій трохи збільшена наявність колагену, сама оболонка осередково потовщена, просвіт артерій середнього калібру зменшений. У мозковій речовині просвіт артерій середнього калібру зменшений. У мозковому шарі спостерігався виражений осередковий набряк і склероз строми, атрофія канальців. Капілярна сітка кори і місцями мозкового шару виявилася досить повнокровною. Таким чином, мікроскопічна картина у нирках даної тварини відображує гіаліноз, фібріноїдні зміни, клітинна реакція, та склероз, що за даними літератури, є послідовними стадіями розвитку сполучної тканини. У цілому ряді клубочків спостерігається тенденція до розвитку склерозу, яка проявляється гіалінозом, розростанням колагенових волокон, наявністю колапсу, набряку, спазму петель капілярів із втратою їх архітектоніки.

III стадія XXН. Мікроскопічне дослідження нирки кота, який загинув на III стадії XXН (вміст креатиніну у сироватці крові 286,0 мкмоль/л), показало наступну картину. У більшості клубочків ниркових тілець рисунок капілярних петель був невиразний, що $\epsilon$ проявом їх колапсу. Спостерігалося розширення і гіаліноз мезангіуму, а також відкладання гіалінових мас між петлями і у просвіті капсули, осередкова проліферація мезангіальних клітин - гломерулогіаліноз. У порожнині капсули було видно різної ступені щільності еозинофільний ексудат, а також розрихлені білкові маси. У поодиноких ниркових клубочках був виражений перигломерулярний склероз, склероз капілярних петель різного ступеня виразності. Зустрічалися також повністю склерозовані клубочки. Частина ниркових тілець була значно зменшена за розмірами, клубочки ниркових тілець у різному ступені гіалінізовані, деякі зморщені та піддані склерозу. Інші ниркові тільця компенсаторно були збільшені за розмірами, гіпертрофовані, капілярні петлі клубочків перебували у стані колапсу, просвіт капсули був збільшений. У деяких із них нирковий клубочок як би підгорнутий до судинного полюсу. Спостерігалася сегментована проліферація мезангіальних клітин, сегментоване розширення та відкладання гіалі- 
нових мас у мезангіумі. Базальні мембрани клітин зовнішнього листка капсули були потовщені та розпушені. Епітелій проксимальних і дистальних канальців нефронів перебували у стані вираженої дистрофії. У ряді випадків цитоплазма нефроцитів набрякла, мутна або дрібнозерниста, або із дрібними гіаліновими крапельками. Часто виражена розпушення і порушення апікальних відділів цитоплазми клітин, у яких видно гіаліноподібні краплі. У просвіті канальців було виявлено багато гіалінових циліндрів. Нефротелій частини трубочок піддався проліферації. У клітинах канальців спостерігалася вакуолізація (жирова дистрофія): вакуолі чітко обмежені, різні за розмірами. У мозковій речовині був виражений набряк і плазматичне просочування інтерстицію, у просвіті трубочок - гіалінові циліндри. У інтерстиціальній тканині місцями було видно осередкові клітинні інфільтрати. Таким чином, у нирках кота, що загинув на III стадії XXН переважали наступні морфологічні зміни: гломерулогіаліноз, склероз окремих клубочків, жирова та гідропічна дистрофія у клітинах ниркових канальців, а також клітинна інфільтрація та набряк інтерстицію.

IV стадія XXН. Гістологічне дослідження нирки кішки, яка загинула в IV стадію XXН (вміст креатиніну у сироватці крові 1034,0 мкмоль/л), показало наступну картину. При мікроскопічному дослідженні нирок було виявлено, що більша частина клубочків ниркових тілець зморщена, гіалінізована, у просвіті капсули - білкові маси. Деякі клубочки частково некротизовані, атрофовані, при цьому відносно невелика кількість клубочків збережена, а значна частина гіпертрофована. Базальна мембрана зовнішнього листка капсули у таких клубочках потовщена, розпушена, ендотеліальні клітини були піддані помірній проліферації. У клубочках відзначається осередкова сегментарна проліферація мезангіальних клітин. Також у нирках кішки, що загинула на IV стадії ХХН, також було виявлено склероз ниркових клубочків різного ступеня виразності - від повного або сегментованого до склероз окремих петель, а також перигломерулярний склероз. У нефроцитах канальців дистального та проксимального відділів нефрону відзначається не різко виражена вакуольна дистрофія, дрібна зернистість, у ряді канальців - гіаліново-крапельна дистрофія, гіалінові циліндри у просвіті. Частина трубочок розширена, нефротелій їх сплощений, іноді видно кістозне розширення трубочок. У стромі коркової речовини спостерігаються великі осередкові лімфогістіоцитарні інфільтрати, склероз із атрофією трубочок, у стромі мозкової речовини - набряк, атрофія канальців, склероз. Також у нирках кішки із XXН на IV стадії було відзначено значне потовщення 
стінки міжчасточкових та внутрішньочасточкових артерій, а також виражений периваскулярний склероз дистрофічні процеси у канальцях мозкової речовини, а також іiї лімфоїдно-гістіоцитарна інфільтрація і склероз. Таким чином, під час морфологічного аналізу препаратів нирок кішки на IV стадії XXH, було визначено наступні зміни: гломерулогіаліноз, гломерулосклероз різної ступені виразності, склероз строми коркової і мозкової речовини нирок, некроз окремих клубочків, а також важкі дистрофічні зміни у ниркових канальцях.

\section{Література:}

1. Brown C.A., Elliott J., Schmiedt C.W., Brown S.A. Chronic Kidney Disease in Aged Cats: Clinical Features, Morphology, and Proposed Pathogeneses. Vet Pathol. 2016. № 53(2): 309-326.

2. Conroy M., Brodbelt D.C., O’Neill D., Chang Y.M., Elliott J. Chronic kidney disease in cats attending primary care practice in the UK: a VetCompass(TM) study. Vet Rec. 2019. № 27; 184(17): 526.

3. Chen H., Avital Y., Bruchim Y., Aroch I., Segev G. Urinary heat shock protein-72: A novel marker of acute kidney injury and chronic kidney disease in cats. Vet J. 2019. № 243: 77-81.

4. Thomson A.L., Berent A.C., Weisse C., Langston C.E. Intra-arterial renal infusion of autologous mesenchymal stem cells for treatment of chronic kidney disease in cats: Phase I clinical trial. $J$ Vet Intern Med. 2019. № 33(3): 1353-1361.

5. Chakrabarti S., Syme H.M., Brown C.A., Elliott J. Histomorphometry of feline chronic kidney disease and correlation with markers of renal dysfunction. Vet Pathol. 2013. № 50(1): 147-155.

6. McLeland S.M., Cianciolo R.E., Duncan C.G., Quimby J.M. A comparison of biochemical and histopathologic staging in cats with chronic kidney disease. Vet Pathol. 2015. № 52(3): 524-534. 